\title{
MARKET ORIENTATION OF BUSINESS SCHOOLS: A DEVELOPMENT OPPORTUNITY FOR THE BUSINESS MODEL OF UNIVERSITY BUSINESS SCHOOLS IN TRANSITION COUNTRIES
}

\section{Maja Rosi, David Tuček, Vojko Potočan, Milan Jurše}

\section{Introduction}

Globalization of higher education and, consequently, of business education, is becoming one of the major challenges for the future development of the academic environment, as it accelerates the international dimension of higher education, which is very important to improve the quality of education, research and other higher education services (Jibeen \& Khan, 2015). The paper's research is limited to business education, whereby the term Business School is used for all highlevel educational institutions that offer study from fields related to Business, Commerce e.g. Economics, Finance, Management (as defined in the Oxford Dictionary). Therefore, terminological limitations should also be noted. When the position of the Business School as an institution of the public higher education system is emphasised, the term University Business School is used. The term "public" in this context means that business school is a public higher education institution that is predominantly funded by public (budgetary) sources of financing and represents public responsibility and public good.

The importance of the internationalization was also discussed in-depth by Altbach and Teichler (2001), claiming that internationalization is inevitable, because it is a part of the global economy, influencing the worldwide labour market for highly skilled personnel. The global economy, and, consequently, internationalization, is also linked to the development of Information-Communication Technologies, representing a powerful tool for diffusing knowledge and information (Larsen \& Lancrin, 2016). However, globalization and internationalization are denoted via several common global trends and phenomena identified by Altbach (2015), such as massification, the impact of the new information and communications technologies, accountability regimes, mobility of students and staff, and global research networks. Also Bradford et al. (2017) discussed internationalization, identifying the main determinants for a successful internationalization, which were divided between external (environmental) and internal pressures (e.g. alignment of the internationalization process with the institution's general strategic plan). Both processes, globalization and internationalization, are changing the European higher education environment (van Vught, 2004), urging schools to find strategies to respond proper to it - in terms of education and research, as well as other education services, such as collaboration with companies.

Business Schools, as an important part of the higher education environment, are additionally facing increased competition (Saginova \& Belyansky, 2008; Thomas \& Cornuel, 2012), because of the fast-growing number of private Business Schools. Other elements influencing increased competition are: Accreditations, as an institutional pressure and exogenous dynamic provider for change (Cooper, 2014), and inevitable international rankings (Altbach, 2006; Wedlin, 2011). These rankings revealed that Business Schools are facing several deficiencies, especially in connection with the (ir)relevance of their research (Starkey et al., 2004; Wilson \& Thomas, 2012), a lack of practice in the business fields (Starkey et al., 2004), and concerns about the sustainability 
of their current business model (Wedlin, 2011). However, these have a great impact on the graduates (Murcia et al., 2016), without relevant competences to allow them to function properly in a business world.

Thus, Business Schools are facing challenges of developing appropriate strategies to cope with all of the requirements of the changing global education market context, ensuring an appropriate position in a competitive environment and creating a relevant framework for future development of their educational and research processes, as well as other services. Business Schools have to create value for companies with knowledge transfer from academia to industry, and build strategic partnerships with businesses from their environment (Paton et al., 2014; Amara et al., 2016). Also, Hawawini (2005) argues an added value of Business Schools in terms of satisfying more complex demands from both students and their employers. Similarly, David et al. (2011), Lorange (2005) and Muff (2012) are outlining the utmost importance of Business Schools finding a way to satisfy stakeholders' expectations. José Chiappetta Jabbour (2010) is focusing on the environmental and social responsibility, arguing the importance of applying environmental management to reduce the impacts on the Business Schools.

Developing an appropriate strategy for meeting the needs of the global market is especially challenging for University Business Schools in transition countries. Thus, this paper is focusing on the University Business Schools in the former socialist countries of Central and Eastern Europe (CEE), where higher education transformation has been embedded in a 'allembracing political, economic and social transformation' (Dobbins \& Kwiek, 2017; Dinu, 2016; Pescu \& Stefan, 2016).

These countries are still confronted with incomplete transition processes in society, especially at the levels of privatization of businesses (Estrin et al., 2009). Countries are further dealing with changes in economic ideology (Dakowska \& Harmsen, 2015) and the changing needs of a transition economy (Saginova \& Belyansky, 2008). The transition process affected University Business Schools in CEE, since they have a legacy in a historically restricted autonomy, regulations and administrative procedures that are limiting their strategic choices (Bleiklie \& Michelsen,
2013; Wilson \& Thomas, 2012). According to Hendel and Lewis (2005), accountability and governance are also major problems in most transition countries. Accountability refers to "a focus on the conditions that must exist within any educational system in order for that system to be accountable for the achievement of its goals" (Barbee \& Bouck, 1974, p. 14). Similar issues were identified by Jurse (2011), arguing that Business Schools in transition countries struggle with the rigidities of their management and leadership concepts and exaggerated embeddedness in their past academic and institutional administrative heritage, which represent a historical barrier for a faster adaptation to existing social changes. Furthermore, Business Schools in transition countries are dealing with unstable sources of financing (Hendel \& Lewis, 2005; Ministr \& Pitner, 2015; Rachwał et al., 2016).

In order to align and increase the responsiveness of University Business Schools in transition countries better with the new globalised business environment, it is important to evaluate their traditional business models and strategic adaptation practices (Verner, 2011). Market orientation is seen as a strategic response of University Business Schools to the globalization challenges and actual market needs. Akonkwa (2013) defined market orientation as a culture and set of activities directed towards the customers' needs, and as the analysis and understanding of the competition and the relevant influences from a broader macro-environment. Narver, Slater and Tietje (1998) also argued that market orientation emphasises the importance of committing all members of an organisation to create added value to their products or services continuously. Another important aspect of market orientation is also gathering information about the competition, which is important in order to maintain the competitive advantage in an increasingly competitive environment (Hemsley-Brown \& Oplatka, 2010).

However, in various studies, the market orientation of Business Schools is addressed only fragmentally, e.g. Mitra (2009) is discussing the transformation of the university from government funding to a marketorientation, which is affecting the social structure of knowledge distribution. Akonkwa (2013) connects the market orientation concept with stakeholder orientation, which is more 
relevant and inclusive as a strategic orientation for the higher education setting. Gill and Lashine (2003) have identified some skills'sets required under a global market environment that identify the need to have market oriented focus in the business education system, etc. Furthermore, when analysing the Business Schools in transition countries, studies are focused mainly on a particular problem and/ or as a case study for the chosen transition country e.g. institutional changes due to the transition process influencing higher education in transition countries (Andrei et al., 2010; Dobbins \& Kwiek, 2017), reforming the higher education system in the context of the Bologna process in Russia (Fardeeva \& Kuzmenko, 2017), quality assurance of higher education in transition countries (Hendel \& Lewis, 2005), changes of education governance and organisational structures in Hungary (Kováts et al., 2017), structural changes in the Polish higher education system (Kwiek, 2014), a case from the Czech Republic about academicindustrial cooperation in ICT (Ministr \& Pitner, 2015) etc.

In order to overcome the fragmentation of market orientation strategies of University Business Schools in transition countries, the goal of this paper was to develop a comprehensive theoretical framework for market orientation of University Business Schools in transition countries as a development opportunity for business education, responding to the changing global education environment. The proposed framework has been validated on 35 University Business Schools in Central and Eastern European transition countries. It emphasises the market orientation of these schools in a more holistic way, since the framework outlines the complexity of their adaptation, considering the linkages and dependencies of all the crucial global external in internal environment trends and aspects.

The rest of the article is organised as follows. First, the introductory part of the research includes a variety of theoretical perspectives about the business education market, its trends and influences on University Business Schools in transition countries. Next, on the basis of Jabareen's (2009) methodology, the theoretical framework was developed and described of a market oriented business model in this schools. The paper is concluded with a discussion and further research opportunities.

\section{Methods Used for Development of the Theoretical Framework}

The aforementioned authors, e.g. Akonkwa (2013), Andrei et al. (2010), Gill and Lashine (2003) and Mitra (2009) addressed the research of market orientation strategies of Business Schools in transition countries fragmentary.

The conceptual framework analysis discussed by Jabareen (2009) was applied in order to conduct a comprehensive theoretical framework as a development opportunity for University Business Schools in transition countries, responding to the changing global education environment in a more market oriented way.

Jabareen (2009) defined a conceptual framework as a network of interlinked concepts that together provide a comprehensive understanding of a phenomenon or phenomena. Conceptual frameworks are products of qualitative analysis processes of theorization, whereby a conceptual framework provides an interpretative approach to social reality. This method is suitable for a multidisciplinary environment (social, cultural, political, and environmental phenomenon, etc.) and use of a variety of types of multidisciplinary literature, such as books, articles, newspapers, essays and practices. With an interpretative approach, collection, comparison and analysis of different types of data, this method provides an opportunity to develop the comprehensive theoretical (conceptual) model (framework) for understanding the complexity of the adaptation of University Business Schools, considering linkages and dependencies of all the crucial global external in internal environment trends and aspects (Jabareen, 2009).

Jabareen (2009) proposed eight stages of this methodology, as shown in Fig. 1: (1) Mapping the selected data sources, (2) Extensive reading and categorising of the selected data, (3) Identifying and naming concepts, (4) Deconstructing and categorising the concepts, (5) Integrating concepts, (6) Synthesis, resynthesis, and making it all make sense, (7) Validating the conceptual framework and (8) Rethinking the conceptual framework. Instead of concepts, that are defined as an idea or a basic principle, this paper explores the factors, which are, according to its definition (several things that cause or affect), more suitable for conducting and explaining the theoretical framework. 


\section{Fig. 1: The procedure of conceptual framework analysis}

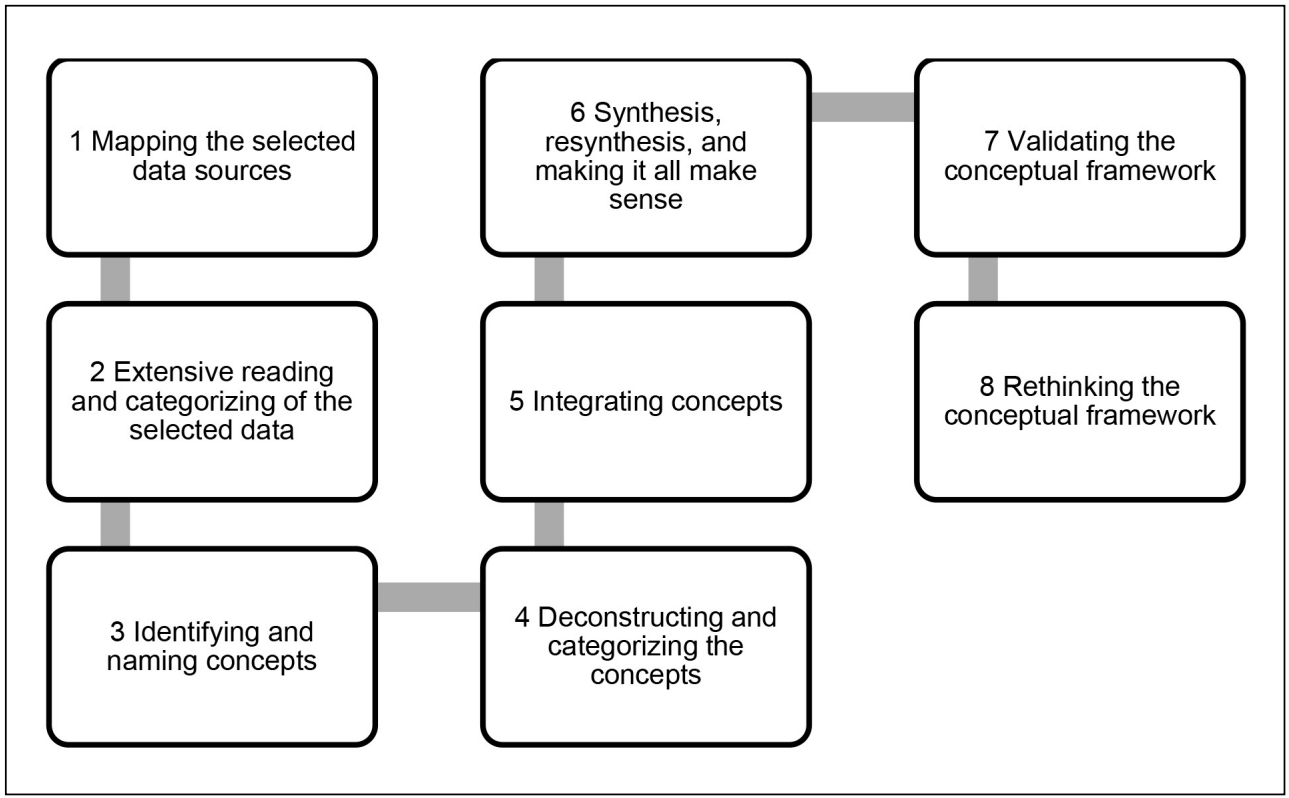

Source: Jabareen (2009)

The research of the market orientation of Business Schools was based on the first three stages of Jabareen's methodology. Mapping of data sources was carried out, with an extensive and comprehensive review of the available literature (such as Altbach, 2006; David et al., 2011; Dinu, 2016; Gill \& Lashine, 2003; Iñiguez de Onzoño \& Carmona, 2007). Then, identification of crucial factors was carried out in the external environment of Business Schools that have a significant impact on the business education market and, simultaneously, reflect the need for ever greater market orientation of Business Schools. These factors highlighted the importance of globalization, internationalization, privatization, changes of the sources of higher education funding, and social responsibility. The main purpose was to overview the global business education environment in order to categorise the selected data. This part of the analysis was concluded with the identification of the factors from the global business education environment impacting University Business Schools in transition countries (as discussed by Andrei et al., 2010; Dakowska \& Harmsen,
2015; Dinu, 2016; Dobbins \& Kwiek, 2017; Estrin et al., 2009; Fardeeva \& Kuzmenko, 2017; Hendel \& Lewis, 2005; Saginova \& Belyansky, 2008).

The stage of deconstructing and categorising of crucial factors revealed some contextual constraints (market, economic, institutional, social, etc.) that should be considered in the market orientation transformation process of University Business Schools in transition countries and, at the same time, in developing the conceptualization of a comprehensive theoretical framework for their appropriate developmental adaptation.

According to fifth stage in Jabareen's (2009) methodology, the factors were integrated and grouped that have a crucial impact on more market oriented alignment of the University Business Schools' model in transition countries. Based on this, 4 key factors were identified that demonstrate the central leverage of the dynamic strategic market adaptation of the University Business Schools in transition countries framework to conditions of an increasingly competitive global business education market: 
(1) Global business education market, (2) Academic-institutional aspects, (3) Social responsibility and (4) Competitive pressures.

With synthesis of these factors, a theoretical framework was designed of market orientation as a development opportunity for University Business Schools in transition countries. The theoretical framework is presented in Fig. 2 and represents a comprehensible conceptual framework of key relevant factors and their interconnections which best describe the research aspect. For the validation purpose, the theoretical framework was validated among representatives of selected University Business Schools from CEE transition countries and rethought in the conclusion of this paper.

\section{Theoretical Framework of a Market Oriented Business Model in University Business Schools in Transition Countries}

The need for a reinforced market orientation of University Business Schools in transition countries is growing. This process should be placed in the context of their overall (institutional) business model, and integrated into their holistic concepts of management, considering both the academic-institutional and socially responsible dimensions, as shown in the theoretical framework of this paper.

The theoretical framework for a market oriented business model for University Business Schools in transition countries illustrates the complexity of adaption of these schools within the market orientation aspect. This article analyses 4 key factors that were identified in the fifth stage of the methodology, which demonstrate the central leverage of a dynamic strategic market adaptation framework of this schools to conditions of an increasingly competitive global business education market.

\subsection{Global Business Education Market}

In the global business education market, University Business Schools in transition countries are facing a new development challenge, i.e., how to transform into modern academic market oriented Business Schools in conditions where these countries are becoming increasingly exposed to international market forces. From a global business education market perspective, important indicators are identified which the management of this schools have to take into consideration:

a) Globalization,

b) internationalization,

c) massification,

d) rise of ICT,

e) economic and political restraints in transition economies,

f) open market economy,

g) increased competition.

Especially, indicators e) - g), that are a reflection of their past transition environment, are forcing them to become more market oriented in order to compete and position themselves in the global education market. On the other hand, these indicators also constrain them in processes of their development. Namely, these countries are facing additional uncertainties that are emerging in the process of transformation from industrial into postindustrial societies (Andrei et al., 2010), significant reforms in almost all sectors, massive organisational restructuring, and increased competition (Saginova \& Belyansky, 2008). The development of the open market economy, forces companies and other market actors into a necessary internationalization of operation and, thereby, creates a stronger demand for better international market visibility and positioning. At the same time, the economic and political transition that reflects in the changes of the ownership structure of the economy and the accelerated privatization, also in the field of Tertiary Education, increased the market competition (Estrin et al., 2009). All these indicators have to be reconsidered, monitored and explicitly integrated into the process of managing those schools, and in structuring the business model with emphasis on a more market oriented aspect.

\subsection{Competitive Pressures}

The global education environment, along with economic and political reforms in transition countries, set new conditions for University Business Schools in these countries, and also strengthened the competitive pressures. The main indicators of competitive pressure, that have the biggest influence on those schools, are:

a) Changing needs of a transition economy: The movement from industrial to postindustrial organisations and workforce demands changes in management practice 
(Szamosi et al., 2008), which also means that University Business Schools have to be flexible enough to provide high quality services to meet the changing needs of a transition economy (Saginova \& Belyansky, 2008).

b) Privatization: Altbach et al. (2009) exposed the dramatic increase of the establishment of new providers of higher education i.e. rapid global development of private higher education institutions, and also to the privatization of public universities, leading to the subsequent aggravated competitive position of Business Schools and the need for market orientation of Business Schools.

c) Meeting market needs: The new market conditions and the privatization process enabled the entry of new companies, increased the movement of commodities, workforce and competition between companies, and exposed the questions regarding the provision of quality services and products for the society (Jurse, 2011). Privatization and the growth of new enterprises opened new employment opportunities which, consequently, increased the need for an appropriately educated workforce, especially in the fields of new technologies, management and other business studies, with the emphasis on up-to-date and practical knowledge and professionally competent individuals (Hashim et al., 2011; Szamosi et al., 2008).

d) Pressures of international evaluation: The business education market is additionally increasingly exposed to the pressures of international evaluation scales for Business Schools and Study Programmes, or to the ranking of Business Schools that dictates new guidelines in order to ensure competition between the providers of business education in the national, regional and global higher education landscape. The public, universities and government bodies find these scales very "popular". Government bodies can regard the results of these scales as one of the criteria for allocation of financial sources to higher education institutions (Altbach et al., 2009; Vidaver-Cohen, 2007).

e) Restricted public funding: As the share of government funding for higher education has declined, Business Schools have become increasingly dependent on fundraising and donations (Cummings, 2011). Within the framework of the increased pressure on public funds, it also became necessary for University Business Schools in transition countries to generate additional sources of income from other resources (Estermann et al., 2013), which proves the need for greater market orientation of their business model. This is also evident from the fact that these schools are affected under the pressure of increases in standardization and institutional isomorphism, as, along with the market of selection and competition, they reflect the need for these schools to develop a distinctive competence that differentiates them from their competitors (Almog-Bareket, 2012).

f) Meeting society needs: Further on, the new competitive environment for University Business Schools in transition countries exposed the questions that indicate new opportunities and their responsibilities which are connected with the sustainable development of the society. It also raised numerous questions regarding the social responsibility of individuals, certain institutions and the entire society, because they are becoming more and more important factors of competitiveness and comparison of companies or economies as a whole with developed market economies in the global market environment.

\subsection{Social Responsibility}

The market orientation of University Business Schools in transition countries has to be reasonably harmonised with the traditional academic values and processes, and balanced with the global responsibility that puts social responsibility, sustainable development, and care for others and nature first. This paper outlines those indicators that are crucial for in their process of becoming more market oriented:

a) Social relevance of Business Schools: Numerous other authors e.g. Hendel and Lewis (2005), Ivory et al. (2008), Santiago et al. (2008), point out the importance of the social relevance of Business Schools, the need for their greater credibility and responsible harmonisation of academic processes with the central challenges of the modern society.

b) Social responsibility: In order to adapt to the new conditions, Business Schools 
should be more responsive to the market and, simultaneously, socially responsible. Welikala (2011) explains social responsibility as the activity to equip members of society with the necessary competencies, knowledge, understanding, and new skills, so that they can negotiate the changing nature of work, the labour force, information technologies and cultural identities of people constantly.

c) Cooperation with the key stakeholders: Business Schools must have the ability to establish relationships with key stakeholders in the social environment in the form of mutual cooperation and explicit commitment, to assure their contribution to the improvement of the social well-being.

d) Delivery of educational services to satisfy a variety of stakeholders: Hashim et al. (2011) exposed the need to be not only responsive to customer groups, but also to provide rigorous, thorough, and relevant educational programmes to serve the long-term interests of students and the institution itself. All of this requires changes of the management, a positive attitude of the Management Board towards changes, and a more active market approach to the changes in the environment (Szamosi et al., 2008). Saginova and Belyansky (2008) are proposing a strategic marketing approach to implement the necessary transformations and delivery of educational services to satisfy a variety of stakeholders of a university, and facilitate positive developments in society.

Those indicators are especially important, since inappropriate care for the environment can impact negatively on the image of the institution and develop a negative attitude of some of the key stakeholders, which can, consequently, also effect the negative operating results of institutions.

\subsection{Academic-Institutional Aspect}

In the global education market, the situation of University Business Schools in transition countries is largely defined, and its powers are limited and influenced by the national and institutional regulations (e.g. legislation, higher education financing model). From the academicinstitutional aspect, the following indicators have the largest impact on those schools: a) Administrative heritage: All organisations in a transition economy, including University Business Schools, are entwined with the administrative heritage of the processes, norms and values associated with the socialist planned economy (Dixon \& Day, 2007).

b) Autonomy in management of Business Schools in transition countries depends to a large extent on the degree of the institutionally assigned (by government authorities and legislation, university regulation) range of decision-making and operation competencies.

c) Complex framework of the management: Due to the complex framework of the management of academic and institutional operation and the influence of the administrative heritage, University Business Schools are usually more rigid in their operation and response to external challenges and pressures, which is why they are not sufficiently capable of adapting flexibly to the changes in the external environment in comparison with the independent private Business Schools (Bartlett \& Ghoshal, 1998; Durand \& Dameron, 2011).

d) Explicit institutionalised aspects of influence on the operation of higher education institutions are realised mostly through the mechanisms and policies regarding the scope and criteria for financing the development of their activities from public (budgetary) sources, and through other formal mechanisms and legislation (usually, excessively rigid), respectively.

e) Accreditation and ranking pressures: The popularity of accreditation creates an institutional environment that exerts pressure on all academic institutions to adopt and preserve the practice of obtaining Accreditation Certificates (Almog-Bareket, 2012). Similarly, with global rankings, whereby universities that are showing outstanding performance in the global rankings gain high international visibility, interest from desirable prospective students and Faculties, and raise additional finance sources (Hazelkorn \& Gibson, 2016).

f) Criticism of Business Schools: From the academic-instructional aspect and also the social environment perspective, there is also a lot of criticism of Business Schools that refers to the irrelevance of research 
findings and their application in economic practice, questionable structure, and relevance of Study Programmes, excessive treatment of students as customers (clients buying educational services), placement of Business Schools on international grading scales, and excessive spending of funds for promotion, inappropriate professional competencies of graduates, etc. (Altbach et al., 2009; Bennis Warren \& O'Toole, 2005; Pfeffer \& Fong, 2002).

As a response to the criticism constraints on the creation of a more proactive institutional market orientation, the institutional academic perspective of a university school raises the question of how to place the implementation of a market orientation into the operating context of the traditional University Business School, whereby an important fact is also social responsibility and the ethical conduct of managers in the business world. This has made Business Schools increasingly exposed to the explicit criticism by various parts of the public regarding the relevance of the knowledge that schools offer to the business world and their graduates in the process of education and development of appropriate professional skills and competencies, adequate awareness of social responsibility, and ethical conduct as the key leverage for their successful performance in the role of promising managers and business professionals in the business world.
Tab. 1 shows key factors and their indicators for a market oriented development of a business model of University Business Schools in transition countries.

Tab. 1 offers a comprehensive review of University Business Schools' environments from transition countries. It outlines the importance of reconsideration of all identified factors, along with all proposed indicators for proper alignment of those schools in their process of becoming more market oriented. Only in this way can a Business School adjust comprehensively enough to become more market oriented and able to compete more successfully with other Business Schools from developed countries on the global education market. All of these indicators create a holistic set of key factors that are constituting the theoretical framework of the market oriented business model in University Business Schools in transition countries, which is shown in Fig. 2.

\section{Results of Theoretical Framework Validation}

Following the seventh stage of Jabareen (2009) methodology, the proposed theoretical framework has to be validated. Thus, a survey among University Business Schools was carried out from selected CEE transition countries (Slovenia, Croatia, Hungary, the Czech Republic, Poland and Lithuania). The questionnaire was addressed to the Management Boards (Dean, Vice-Dean,

\section{Tab. 1: Synthesis factors for market oriented development of a business model of University Business Schools in transition countries}

\begin{tabular}{l|l}
\multicolumn{1}{c|}{ Key factors } & \multicolumn{1}{c}{ Indicators } \\
\hline $\begin{array}{l}\text { Global education } \\
\text { market }\end{array}$ & $\begin{array}{l}\text { Globalization, internationalization, massification, rise of ICT, economic } \\
\text { and political constraints in transition economies, open market economy } \\
\text { and increased competition. }\end{array}$ \\
\hline Competitive pressures & $\begin{array}{l}\text { Pressures of international evaluation, privatization, changing needs } \\
\text { of a transition economy, restricted public funding, meeting society } \\
\text { and market needs. }\end{array}$ \\
\hline Social responsibility & $\begin{array}{l}\text { Social relevance of Business Schools, social responsibility, cooperation } \\
\text { with the key stakeholders, delivery of educational services to satisfy } \\
\text { a variety of stakeholders. }\end{array}$ \\
\hline $\begin{array}{l}\text { Academic-institutional } \\
\text { aspects }\end{array}$ & $\begin{array}{l}\text { Administrative heritage, autonomy, complex framework of the } \\
\text { management, explicit institutionalised aspects, accreditation and ranking } \\
\text { pressures, criticism of Business Schools. }\end{array}$ \\
\hline
\end{tabular}




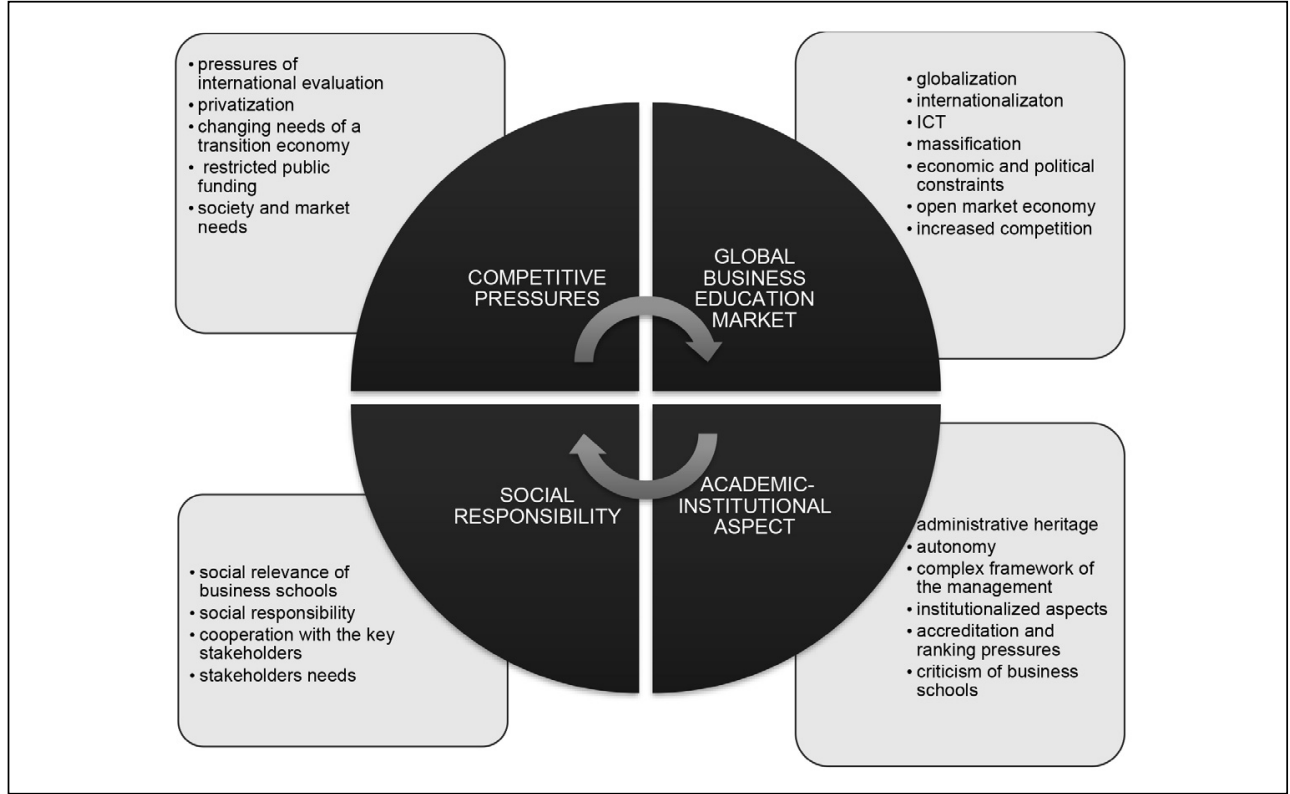

Source: own

Manager) of 60 selected schools, whereby 35 respondents from different University Business Schools completed the survey (7 from Slovenia, 8 from Croatia, 6 from Hungary, 3 from the Czech Republic, 6 from Poland and 5 from Lithuania).

The questionnaire was based on a five-point Likert-type scale (Likert, 1967) ranging from 5 (clearly true) to 1 (clearly not true) used for variables (V1-V17, V32-V36), while for variables V18-V31 the following Likert-type scale was used from 5 (very important challenge) to 1 (unimportant challenge). For the purpose of the seventh and eighth steps of the conceptual framework analysis, the arithmetic mean was used, as the most important and most frequently calculated mean value (Bastič, 2006). As a measure of the representability of the arithmetic mean, Standard Deviation was calculated, whereby the smaller the Standard Deviation (in comparison with the arithmetic mean) is, the smaller are the differences between the actual values of the variable and its arithmetic mean, and vice versa (Bastič, 2006). To test reliability, the questionnaire's Cronbach's a magnitude was set at 0.912 , which is considered to be high (Ferligoj et al., 1995).

The aim of the survey was to determine to what extent schools implement market orientation principles regarding the global education market, competitive pressure, social responsibility and academic-institutional aspects in their business model in order to validate and rethink the proposed theoretical framework.

The first part of the questions (V1-V4) were related to the academic-institutional aspect of their business, the second part (V5-V22) to competitive pressures that influence their business operations and actions, the third part (V23-V31) to global education market influences, and the last part (V32-V36) to social responsibility issues. Additionally, the respondents were asked about the implementation of social responsibility, source of their financial incomes and structure of their funding.

Tab. 2 presents the results of descriptive statistics, with the arithmetical means and Standard Deviations for each of the variable (for all 35 respondents). 


\begin{tabular}{|c|c|c|c|}
\hline Tab. 2: & \multicolumn{3}{|c|}{$\begin{array}{l}\text { Descriptive statistics, with the arithmetical mean and standard deviations } \\
\text { for variables V1-V36 (Part 1) }\end{array}$} \\
\hline No & Variable & Mean & SD \\
\hline V1 & $\begin{array}{l}\text { The functioning of our institution is still influenced by prior institutional models } \\
\text { and patterns and is thus difficult to change. }\end{array}$ & 4.06 & 1.24 \\
\hline V2 & $\begin{array}{l}\text { Our institution is too involved in the local over-regulated institutional } \\
\text { framework and, in terms of competitiveness, in a closed academic } \\
\text { environment. }\end{array}$ & 4.14 & 0.85 \\
\hline V3 & $\begin{array}{l}\text { Legal restrictions impede our independent efforts to strengthen international } \\
\text { competitiveness. }\end{array}$ & 3.20 & 1.21 \\
\hline V4 & In decision-making, our business school is completely autonomous. & 2.43 & 1.15 \\
\hline V5 & $\begin{array}{l}\text { Responsiveness (in research and education) regarding the development } \\
\text { needs of the society is a key element in the success of our institution. }\end{array}$ & 2.41 & 0.98 \\
\hline V6 & $\begin{array}{l}\text { The aim of our institution is to obtain at least } 50 \% \text { of school budged from } \\
\text { private sources (sponsorships, donations, fees, marketing activities). }\end{array}$ & 2.33 & 1.38 \\
\hline V7 & $\begin{array}{l}\text { We regularly analyse the competitive advantages of our major competitors } \\
\text { and the reasons why students from competing schools chose against } \\
\text { studying at our institution. }\end{array}$ & 3.37 & 1.09 \\
\hline V8 & $\begin{array}{l}\text { At our institution, we do our best to co-operate as much as possible } \\
\text { with companies (the economy) and relevant institutions, i.e. users of our } \\
\text { knowledge and employers of our graduates. }\end{array}$ & 4.17 & 0.89 \\
\hline V9 & $\begin{array}{l}\text { We regularly try to identify the most important opportunities and challenges in } \\
\text { the environment that could affect our business operations. }\end{array}$ & 3.86 & 0.91 \\
\hline V10 & $\begin{array}{l}\text { It is vital to actively strengthen the position of our institution on the business } \\
\text { education market (counselling, education, research), in order to seek } \\
\text { additional sources of financing. }\end{array}$ & 4.03 & 0.86 \\
\hline V11 & $\begin{array}{l}\text { In order to increase the relevance of new knowledge and facilitate the } \\
\text { positioning of our institution on the market of business education, research } \\
\text { priorities are adapted to the needs of key stakeholders (the economy, } \\
\text { government institutions, etc.). }\end{array}$ & 3.60 & 0.95 \\
\hline V12 & $\begin{array}{l}\text { In developing the content of study programmes and curricula the needs and } \\
\text { suggestions of our key stakeholders (business representatives, government } \\
\text { institutions, etc.) are taken into account. }\end{array}$ & 3.69 & 0.96 \\
\hline V13 & $\begin{array}{l}\text { For the purpose of enhancing the international visibility of our institution, } \\
\text { the key strategic objective over the next } 3-5 \text { years is to be featured in major } \\
\text { international rankings of top quality business schools or to raise our current } \\
\text { position in them. }\end{array}$ & 3.51 & 1.2 \\
\hline V14 & At our institution, we facilitate interdisciplinary of research. & 3.83 & 0.82 \\
\hline V15 & At our institution, we encourage students to participate in research activities. & 4.09 & 0.89 \\
\hline V16 & $\begin{array}{l}\text { At our institution, the internationalization of study programmes and the } \\
\text { curriculum (content of study programmes) are one of the main priorities. }\end{array}$ & 4.34 & 0.80 \\
\hline V17 & $\begin{array}{l}\text { The process of managing our business school is constantly adapted to the } \\
\text { changes in the wider (even international) environment. }\end{array}$ & 3.34 & 0.97 \\
\hline V18 & National competitiveness in the field of education & 4.06 & 1.24 \\
\hline V19 & International competitiveness of business education & 3.91 & 1.15 \\
\hline V20 & The objective to rank at international business schools rankings & 3.80 & 1.08 \\
\hline V21 & $\begin{array}{l}\text { The main considerations in curriculum development are the professional } \\
\text { competencies, which meet the needs of students and employers. }\end{array}$ & 4.29 & 0.93 \\
\hline
\end{tabular}




\begin{tabular}{|c|c|c|c|}
\hline Tab. 2: & \multicolumn{3}{|c|}{$\begin{array}{l}\text { Descriptive statistics, with the arithmetical mean and standard deviations } \\
\text { for variables V1-V36 (Part 2) }\end{array}$} \\
\hline No & Variable & Mean & SD \\
\hline V22 & Excellence in research and education & 4.43 & 0.88 \\
\hline V23 & Internationalisation of study programmes & 4.37 & 0.88 \\
\hline V24 & Internationalisation of academic activities & 4.26 & 0.85 \\
\hline V25 & Use of new technology and high-quality IT & 4.14 & 0.85 \\
\hline V26 & International cooperation in the field of education and research & 4.43 & 0.95 \\
\hline V27 & International academic staff mobility & 4.29 & 0.83 \\
\hline V28 & International student mobility & 4.38 & 0.78 \\
\hline V29 & $\begin{array}{l}\text { Programmes (lifelong learning, programmes in foreign languages, managerial } \\
\text { education) are adapted to specific target groups (regular, irregular students) }\end{array}$ & 3.91 & 1.04 \\
\hline V30 & Marketing activities for attracting new students & 4.35 & 0.85 \\
\hline V31 & Clear international visibility in the field of business education. & 4.14 & 0.69 \\
\hline V32 & Our management policy is oriented towards socially responsible practices. & 3.83 & 0.79 \\
\hline V33 & $\begin{array}{l}\text { Social responsibility is a key factor in building a competitive advantage and in } \\
\text { Developing our identity for the purposes of marketing. }\end{array}$ & 3.57 & 0.92 \\
\hline V34 & $\begin{array}{l}\text { Our students show great interest in the contents of socially responsible } \\
\text { behaviour. }\end{array}$ & 3.51 & 0.92 \\
\hline V35 & $\begin{array}{l}\text { Our school allows students to gain skills and experience to make an informed } \\
\text { Contribution to the development of sustainable and responsible society. }\end{array}$ & 3.97 & 0.82 \\
\hline V36 & $\begin{array}{l}\text { Objectives and principles of managing our institutions are explicitly specified } \\
\text { in our strategic plan. }\end{array}$ & 3.97 & 0.92 \\
\hline
\end{tabular}

Based on the results in Tab. 2, with respect to the academic-institutional aspect, it can be observed that the highest mean value was 4.14 in V2 (Our institution is too involved in the local over-regulated institutional framework and, in terms of competitiveness, in a closed academic environment). Also V1 (The functioning of our institution is still influenced by prior institutional models and patterns and is thus difficult to change) with the mean value 4.06 , and variables V3 (Legal restrictions impede our independent efforts to strengthen international competitiveness), and V4 (In decision-making, our business school is completely autonomous) with lower mean values, indicate that these schools are faced with rigid institutional, administrative and academic regulations, as well as by an increasingly institutionalised and autonomous university administration.

With respect to the competitive pressures aspect, from Tab. 2 it is possible to detect the presence of extensive competitive pressures, since all respondents evaluated variables $\mathrm{V} 18-\mathrm{V} 22$, that indicate this as an important challenge for their institutions. Mean values of variables V8-V16 were between 3.51 and 4.34 - showing that all respondents listed these competitive pressures' indicators as a true fact for their institutions. With the exception of variable V7 (We analyse the competitive advantages of our major competitors and the reasons why students from competing schools chose against studying at our institution regularly) and V17 (The process of managing our business school is constantly adapted to the changes in the wider (even international) environment), where mean values indicate their indifferent attitude toward this practice experience. Another exception, were variables V5 (Responsiveness (in research and education) regarding the development needs of society is a key element in the success of our institution) with mean value 2.41 , and variable V6 (The aim of our institution is to obtain at least $50 \%$ of school budget from private sources (sponsorships, donations, fees, marketing activities) with the lowest mean value 2.33. According to financial sources, respondents were asked to specify 
the structure of their funding. Results show that the main part of funding still represents public funding with $59.31 \%$. Tuition fees present then $9.43 \%$, revenues from research $4 \%$, revenues from consultations $0.74 \%$ and $1.94 \%$ other financial sources.

Variables (V23-V31) related to the global education market aspect indicate positive attitudes towards global education market challenges, since all respondents rated this variable on average as an important challenge. The highest mean value was 4.43 in variable V26 (International cooperation in the field of education and research).
Regarding social responsibility aspect, the mean value of variables V32-V36 was between 3.51 and 3.97. This indicates that all business schools evaluate these experiences as true fact for their institutions. According to the additional question, where they had to specify, which aspects of social responsibility their institutions carry out, the results are in Tab. 3. Most of the schools $(71 \%)$ do carry out ethical work practices and $60 \%$ of all schools do provide equal career and development opportunities for their employees. Only $20 \%$ of them are engaging sponsorships/funding activities.

\section{Tab. 3: Implementation of activities related to social responsibility}

\begin{tabular}{l|c}
\multicolumn{1}{c|}{ Activities } & Share of schools in \% \\
\hline Continuous contribution to the development of local environment & $50 \%$ \\
\hline $\begin{array}{l}\text { Employee wellbeing (safety, social standards, measuring employee } \\
\text { satisfaction) }\end{array}$ & $45 \%$ \\
\hline Active efforts for environmental protection and resource efficiency & $42 \%$ \\
\hline Providing equal career and development opportunities & $60 \%$ \\
\hline Ethical work practices & $71 \%$ \\
\hline Sponsorships/funding & $20 \%$ \\
\hline Respect for fundamental human rights & $58 \%$ \\
\hline $\begin{array}{l}\text { An honest and fair relationship with key stakeholders (consumers-students, } \\
\text { employees and other key stakeholders) }\end{array}$ & $30 \%$ \\
\hline Facilitating volunteer work amongst employees and students & $35 \%$ \\
\hline
\end{tabular}

Source: own

\section{Discussion}

Structuring the theoretical framework for the development of a business model for the assurance of greater market orientation of University Business Schools in transition countries is a complex process, which depends on many factors that hinder or promote this process. The process of a structured adaptation depends largely on the level of autonomy of those schools in decision-making and operation within the university's academic and management system, and the ability of overcoming the rigidities arising from the administrative heritage, which especially evident in a variety of traditional patterns of operation and adaptation within the rigidly regulated institutional national higher education system in individual countries. It also depends on a local country's governmental regulating system, its influence on the operation of higher education institutions, the extent and criteria for financing the development of their activities from public resources (budget), and the accepted regulative frameworks (legislation), which is often a result of forced political adjustment in the presence of the interests and influences of various social actors, especially in view of the regulative power of the governing political elites. 
The results in the validation stage indicate that selected University Business Schools from transition countries are faced with rigid institutional, administrative and academic regulations, as well as by an increasingly institutionalised and autonomous university administration, which is a clear obstacle in their process of becoming more market oriented. Additionally, they are not making enough effort to obtain other financing sources, since the variable V6 indicates that these schools have made no attempt to obtain extra budget from private sources (sponsorships, donations, fees, marketing activities) and since it can be observed that the main part of funding are public sources. Finding additional financial sources is a crucial aspect for appropriate market orientation, so, for those schools, it is essential to obtain additional sources from the market, as already noted by numerous authors; e.g. Kaplan (2018) and Pucciarelli and Kaplan (2016) who are outlining the importance of searching for new financial resources in the marketplace (designing fundraising activities, executive education activities etc.) This would enable them to achieve a more visible position for their business school in an increasingly competitive global business education market as a result of their continuous effort to strengthen the business school's competitiveness.

Regarding the global business education market, survey respondents rated its indicators (e.g. internationalization activities, use of ICT, international cooperation, global visibility) as an important challenge for their schools. These outcomes are in line with previous studies (e.g. Altbach et al., 2009; Altbach, 2015; Jibeen \& Khan, 2015; Lorange, 2005) that emphasise the importance of global trends in the higher education marketplace and need for proper adjustment of business schools' institutions to these trends; particularly those ones in transition countries (as noticed by Jurse, 2011; Kraft \& Vodopoviec, 2003; Saginova \& Belyansky, 2008).

Despite the fact that these schools are becoming more and more exposed to the global business education market and its challenges that force them into more market orientated business, on average none of these activities were rated as very important challenges. Similar were rated competitive pressure challenges, since they show up awareness for national and international competitiveness, international business schools rankings' importance, meeting the needs of students and employers, and displaying excellence in research and education. But still, on average, none of these challenges were rated as very important challenges for their institution. For improving their competitive responsiveness regarding the development needs of society (which was, on average, rated as not a true fact for their institution), and regarding the other external challenges, they have to create a better market-oriented alignment to a dynamically changing business education market, as already discussed by Hawawini (2005), Hemsley-Brown and Oplatka (2010), Mitra (2009), Tran et al. (2015).

Along with a higher degree of responsiveness in their market-oriented attitudes towards their customers (students, business firms and other employees), these schools are also expected to be more engaged and socially responsible in their interaction with other stakeholders in a broader society. Regarding this issue, results demonstrate the implementation of several activities related to social responsibility, but there is still a lot of room for improvement that would enable them to create a distinctive clear and consistent visibility along key stakeholders and competitive market position. According to Brik et al. (2011) Corporate Social Responsibility activities influence the effectiveness of market orientation, since they focus primarily on an organisation's ability and willingness to serve its stakeholders.

The results of the study show a holistic nature and the complexity of the structure and processes of the market oriented business model of University Business Schools in transition countries that, from the perspective of influences, as well as final results, has to take into account the interrelation and (co) dependence of the factors identified and evaluated in this study. It is certainly becoming obvious that, for these schools that create the value of their services for the stakeholders in a congested business education market context, the increasing market proactivity is becoming an increasingly important lever for the improvement of their effectiveness and performance, and particularly, for developing and defending their desired positions in the in a dynamically changing competitive global market for business education services. As stated by Webster et al. (2005), the 
market oriented organization recognises the importance of harmonization of the activity of all departments, functions and individuals in a certain organisation in order to be able to satisfy its customers in the market by providing them with better value of the offered products or services. Market oriented organisation collects data regularly about its customers, competition and the market where it operates in order to be able to plan and provide better value to its customers and to maintain the competitive advantage in an increasingly competitive environment (Hemsley-Brown \& Oplatka, 2010). Market orientation also requires strategic response by University Business Schools to the actual market needs, and a focused attention to the orientation towards wider social community needs. This also includes the reconsideration of the appropriate ways for the assurance of better responsiveness to customer needs (Akonkwa, 2013), improve the quality of management, and the needs for greater global sensitivity towards the external context - all with the objective to realise customer needs early and to respond promptly with the appropriate offer of services (knowledge, information, professional competencies, consultation, etc.), as well as products that are that are deemed important for a successful operation in an increasingly competitive business education market (Bradshaw, 2011; Stankevičienè \& Vaiciukevičiūtè, 2016).

The results have shown that, in order to become more market oriented, University Business Schools from transition countries have to take into account numerous levers from the wider global environment, which are consistent with those revealed in the previous studies e.g. Hemsley-Brown and Oplatka (2010); Marsikova and Urbánek (2015); Mitra (2009); Tran et al. (2015); Webster et al. (2005). This also includes the accompanying factors of the transition process, that, according to numerous authors (e.g. Berryman, 2000; Estrin et al., 2009; Próchniak; 2011; Saginova \& Belyansky, 2008), reflect in the economy privatization processes, greater degree of openness of the local markets to international competitors, and the strengthened integration of local business operators in the international economy, as well as in an increasingly visible institutional measures and practices aimed at the reduction of public sources of financing for higher education or changes in the national budgetary financing structures, etc. Contrary to the findings from previous fragmentary studies, a key contribution of this paper lies, first, in the theoretically founded and empirically verified recognition of a necessity for a requisitely holistic approach in the critical reconsideration of the traditional business model of University Business Schools in transition countries, and, second, in proposing a holistic strategic framework of the University Business School adaptation practices for their better alignment to new realities in society, and particularly in the business education market. Third, an integrated theoretical framework of market oriented business model in University Business Schools in transition countries is presented in which key contextual factors are considered as a complex set of factors that should be considered in the process of comprehensive and dynamic adaptation of schools to changing realities in external environment of business education.

Unlike previous research, this theoretical framework emphasises the need for a much deeper understanding of the complex interdependencies of the academic management concepts with market orientation as a philosophy of business operations of their schools that also relies on relevant socially responsible modes of operating in their external environment. These dimensions form in their fundamental intertwining a theoretical framework (a socially responsive academicmarket business model) for a more holistic approach towards developing strategies for a greater consistent and comprehensive response of the University Business Schools in transition countries to the challenges of their external environment. This also means developing appropriate schools' strategies for improving their desired market positioning and capability for meeting the expectations of various social stakeholders and the challenges of other players on the market and in a wider academic community successfully in the context of growing complexities, and the dynamic development of the global business education market, as has already been discussed by Akonkwa (2013), David et al. (2011), Lorange (2005), Muff (2012) and others. However, it is primarily the task of the management of each individual university business school to formulate the most appropriate operational framework for incorporating market orientation into a business model of the school in such 
a way that it will not pose a threat to its existing business model, but rather an important lever to strengthen the school's competitiveness in the business education market. Thus, business school managers and deans must be able to extend the logics of a traditional academic model of a University Business School in a creative way into an effective academic-market business model, and place it comprehensively enough in the framework of socially responsible behaviour as a way of carrying out its academic, market and other activities in the environment.

\section{Conclusions}

University Business Schools in transition countries are faced with a number of radical challenges, among which the most relevant are the globalization of the market and competition, the development of a market economy and privatization of businesses and other key institutions in those societies, the restrictive funding of higher education from public sources (national budgets), increased institutional and competitive pressures on higher education, and, last but not least, the process of accelerated globalization of the market for business education services. Due to the increased volatility of the external context, the basic strategic and operative frameworks of their business models are changing. An increasingly competitive business education market forces University Business Schools from transition countries to show a higher degree of responsiveness in their market oriented attitudes towards their customers (students, business firms and other employees), and more engaged and socially responsible behaviour in their interaction with other stakeholders in a broader society.

The paper developed and validated a theoretical framework for the long-term success of University Business Schools in transition countries by the transformation of their traditional business models, which takes into consideration the principles of market orientation as a development opportunity for creating the sustainable competitive position of University Business Schools in the global business education market. As it is shown in theoretical framework, and with the aspect of the complex (co)dependence on numerous other factors, inevitably, in the future, they will be forced to become more market oriented, which is an important academic and business dimension of their strategic development transformation.

Thus, the results of the paper bring added value to the scientific community in this field, because it clearly overcomes the previous fragmentary studies of this research field and proposes a requisitely holistic approach in the critical reconsideration of the traditional business model of University Business Schools in transition countries.

The validation process of the framework indicated the utmost importance of the selected key factors (global education market, competitive pressure, academic-institutional aspect, social responsibilities) and their indicators. The overall results demonstrate the need for a greater market orientation of University Business Schools in transition countries, synthesised in a theoretical framework. The proposed theoretical framework is dynamic, and represents a multidisciplinary phenomenon, which could be revised in future research. At this stage of rethinking the conceptual framework, the theoretical perspective could be enlarged by weighting of the key factors of the proposed framework. This method could provide a comprehensive framework to the Management Boards of those schools in transition countries for organising and analysing decisions regarding their future development in the global business education market. 


\section{References}

Akonkwa, D. B. M. (2013). Beyond market orientation: An operationalisation of stakeholder orientation in higher education. African Journal of Marketing Management, 5(3), 68-81. https://dx.doi.org/10.5897/AJMM2013.0294.

Almog-Bareket, G. (2012). Visionary leadership in business schools: an institutional framework. Journal of management development, 31(4), 431440. https://dx.doi.org/10.1108/02621711211219086.

Altbach, P. G. (2006). The dilemmas of ranking. International Higher Education, (42), 2-3. https://doi.org/10.6017/ihe.2006.42.7878.

Altbach, P. G. (2015). Higher education and the WTO: Globalization run amok. International Higher Education, (23), 2-4. https://dx.doi. org/10.6017/ihe.2001.25.6947.

Altbach, P. G., Reisberg, L., \& Rumbley, L. E. (2009). Trends in global higher education: Tracking an academic revolution. A Report Prepared for the UNESCO 2009 World Conference on Higher Education. UNESCO.

Altbach, P. G., \& Teichler, U. (2001). Internationalization and exchanges in a globalized university. Journal of Studies in International Education, 5(1), 5-25. https://dx.doi.org/10.1177/102831530151002.

Amara, N., Halilem, N., \& Traoré, N. (2016). Adding value to companies' value chain: Role of business schools scholars. Journal of Business Research, 69(5), 1661-1668. https://dx.doi. org/10.1016/j.jbusres.2015.10.035.

Andrei, T., Teodorescu, D., \& Oancea, B. (2010). Characteristics of higher education in Romania during transition. Procedia-Social and Behavioral Sciences, 2(2), 3417-3421. https://dx.doi.org/10.1016/j.sbspro.2010.03.526.

Barbee, D. E., \& Bouck, A. J. (1974). Accountability in education. Petrocelli Books.

Bartlett, C. A., \& Ghoshal, S. (1998). Beyond strategic planning to organization learning: Lifeblood of the individualized corporation. Strategy \& Leadership, 26(1), 34-39. https://dx.doi.org/10.1108/eb054610.

Bastič, M. (2006). Metode raziskovanja. Maribor: Univerza v Mariboru, Ekonomsko poslovna fakulteta Maribor.

Bennis, W. G., \& O' Toole, J. (2005). How business schools lost their way. Harvard Business Review, 83(5), 96-104.

Berryman, S. E. (2000). Hidden challenges to education systems in transition economies. World Bank Publications. https://dx.doi. org/10.1596/0-8213-4813-2.
Bleiklie, I., \& Michelsen, S. (2013). Comparing $\mathrm{HE}$ policies in Europe. Higher Education, 65(1), 113-133. https://dx.doi. org/10.1007/s10734-012-9584-6.

Bradford, H., Guzmán, A., \& Trujillo, M. A. (2017). Determinants of successful internationalisation processes in business schools. Journal of Higher Education Policy and Management, 39(4), 435-452. https://dx.doi.org/ 10.1080/1360080X.2017.1330798.

Bradshaw, D. (2011). Business school strategy: customer becomes king. Financial Training 2011. Financial Times.

Brik, A. B., Rettab, B., \& Mellahi, K. (2011). Market orientation, corporate social responsibility, and business performance. Journal of Business Ethics, 99(3), 307-324. https://doi.org/10.1007/s10551-010-0658-z.

Cooper, S., Parkes, C., \& Blewitt, J. (2014). Can accreditation help a leopard change its spots?: Social accountability and stakeholder engagement in business schools. Accounting, Auditing \& Accountability Journal, 27(2), 234-258. https://dx.doi.org/10.1108/AAAJ-072012-01062.

Cummings, T. G. (2011). How business schools shape (misshape) management research. In S. A. Mohrman, \& E. E. Lawler (Eds.), Useful Research: Advancing Theory and Practice. San Francisco, CA: Berrett-Koehler Publishers.

Dakowska, D., \& Harmsen, R. (2015). Laboratories of reform? The Europeanization and internationalization of higher education in Central and Eastern Europe. European Journal of Higher Education, 5(1), 4-17. https://dx.doi.or g/10.1080/21568235.2014.977318.

David, F. R., David, M. E., \& David, F. R. (2011). What are business schools doing for business today? Business Horizons, 54(1), 51-62. https://dx.doi.org/10.1016/j. bushor.2010.09.001.

Dinu, V. (2016). The constraints to the economic development in the former socialist EU countries from the Central and Eastern Europe. Amfiteatru Economic, 18(43), 499-501.

Dixon, S. E., \& Day, M. (2007). Leadership, administrative heritage and absorptive capacity. Leadership \& Organization Development Journal, 28(8), 727-748. https://dx.doi. org/10.1108/01437730710835461.

Dobbins, M., \& Kwiek, M. (2017). Europeanisation and globalisation in higher education in Central and Eastern Europe: 25 years of changes revisited (1990-2015). 
EERJ - European Educational Research Journal, 16(5), 519-528. https://dx.doi. org/10.1177/1474904117728132.

Durand, T., \& Dameron, S. (2011). Where have all the business schools gone? British Journal of Management, 22(3), 559-563. https://dx.doi.org/10.1111/j.1467-8551.2011.00775.x.

Estermann, T., Pruvot, E. B., \& ClaeysKulik, A.-L. (2013). Designing strategies for efficient funding of higher education in Europe. DEFINE interim report.

Estrin, S., Hanousek, J., Kočenda, E., \& Svejnar, J. (2009). The effects of privatization and ownership in transition economies. Journal of Economic Literature, 47(3), 699-728. https://dx.doi.org/10.1257/jel.47.3.699.

Fardeeva, I. N., \& Kuzmenko, V. I. (2017). Reforming the system of higher education in Russia in the context of the Bologna Process. Modern Journal of Language Teaching Methods, 7(9), 593-597.

Ferligoj, A., Leskošek, K., \& Kogovšek, T. (1995). Zanesljivost in veljavnost merjenja. Ljublana: Fakulteta za družbene vede.

Gill, A., \& Lashine, S. (2003). Business education: a strategic market-oriented focus. International Journal of Educational Management, 17(5), 188-194. https://doi. org/10.1108/09513540310484904.

Hashim, F., Bakar, A., \& Rahim, A. (2011). Antecedents and consequences of market orientation in non-profit organizations: evidence from Malaysia. International Journal of Management and Marketing Research, 4(3), 95-105.

Hawawini, G. (2005). The future of business schools. Journal of Management Development, 24(9), 770-782. https://dx.doi. org/10.1108/02621710510621286.

Hazelkorn, E., \& Gibson, A. (2016). Another Year, Another Methodology: Are Rankings Telling Us Anything New? International Higher Education, (84), 3-4. https://dx.doi.org/10.6017/ ihe.2016.84.9105.

Hemsley-Brown, J., \& Oplatka, I. (2010). Market orientation in universities: A comparative study of two national higher education systems. International Journal of Educational Management, 24(3), 204-220. https://doi.org/10.1108/09513541011031565.

Hendel, D. D., \& Lewis, D. R. (2005). Quality assurance of higher education in transition countries: Accreditation-accountability and assessment. Tertiary Education \& Management,
11(3), 239-258. https://dx.doi.org/10.1080/1358 3883.2005.9967149.

Iñiguez de Onzoño, S., \& Carmona, S. (2007). The changing business model of B-schools. Journal of Management Development, 26(1), 22-32. https://dx.doi. org/10.1108/02621710710720059.

Ivory, C., Miskell, P., Shipton, H., White, A., Neely, A., \& Davies, J. (2008). Leadership of business schools: perceptions, priorities and predicaments. Research Report. AIM - The Advanced Institute of Management Research.

Jabareen, Y. (2009). Building a conceptual framework: philosophy, definitions, and procedure. International Journal of Qualitative Methods, 8(4), 49-62. https://dx.doi. org/10.1177/160940690900800406.

Jibeen, T., \& Khan, M. A. (2015). Internationalization of Higher Education: Potential Benefits and Costs. International Journal of Evaluation and Research in Education, 4(4), 196-199.

José Chiappetta Jabbour, C. (2010). Greening of business schools: a systemic view. International Journal of Sustainability in Higher Education, 11(1), 49-60. https://dx.doi. org/10.1108/14676371011010048.

Jurse, M. (2011). A market perspective of aligning university business education in transition countries with the emerging globalisation of higher education. Transformation in Business \& Economics, 10(2), 104-124.

Kaplan, A. (2018). A school is "a building that has four walls... with tomorrow inside": Toward the reinvention of the business school. Business Horizons, 61(4), 599-608. https:// dx.doi.org/10.1016/j.bushor.2018.03.010.

Kováts, G., Heidrich, B., \& Chandler, N. (2017). The pendulum strikes back? An analysis of the evolution of Hungarian higher education governance and organisational structures since the 1980s. European Educational Research Journal, 16(5), 568-587. https://dx.doi. org/10.1177/1474904117697716.

Kraft, E., \& Vodopoviec, M. (2003). The new kids on the block: The entry of private business schools in transition economies. Education Economics, 11(3), 239-257. https://dx.doi.org/ 10.1080/0964529032000178437.

Kwiek, M. (2014). Structural changes in the Polish higher education system (1990-2010): A synthetic view. European Journal of Higher Education, 4(3), 266-280. https://dx.doi.org/ 10.1080/21568235.2014.905965. 
Larsen, K., \& Vincent-Lancrin, S. (2016). The impact of ICT on tertiary education: Advances and promises. SKAP Journal, 4(1), 167-184.

Likert, R. (1967). The Method of Constructing an Attitude Scale. Readings in Attitude Theory and Measurement. New York: Wiley.

Lorange, P. (2005). Strategy means choice: also for today's business school! Journal of management development, 24(9), 783-790. https://dx.doi.org/10.1108/02621710510621295.

Marsikova, K., \& Urbánek, V. (2015). A comparison of educational mismatches across Europe. E\&M Ekonomie a Management, 18(4), 24-38. https://dx.doi.org/10.15240/ tul/001/2015-4-002.

Ministr, J., \& Pitner, T. (2015). Academicindustrial cooperation in ICT in a transition economy-Two cases from the Czech Republic. Information Technology for Development, 21(3), 480-491. https://dx.doi.org/10.1080/026 81102.2014.903887.

Mitra, S. K. (2009). Why Universities Are Adopting Market Oriented Management Practices? Asian Social Science, 5(3), 137142. https://dx.doi.org/10.5539/ass.v5n3p137.

Muff, K. (2012). Are business schools doing their job? Journal of Management Development, 31(7), 648-662. https://dx.doi. org/10.1108/02621711211243854.

Murcia, M. J., Rocha, H. O., \& Birkinshaw, J. (2016). Business Schools at the crossroads? A trip back from Sparta to Athens. Journal of Business Ethics, 150(2), 579-591. https://doi. org/10.1007/s10551-016-3129-3.

Paton, S., Chia, R., \& Burt, G. (2014). Relevance or 'relevate'? How university business schools can add value through reflexively learning from strategic partnerships with business. Management Learning, 45(3), 267-288. https://dx.doi. org/10.1177/1350507613479541.

Pescu, M., \& Stefan, C. (2016). The effects of gaps and disparities on economic growth. A study of 10 former socialist countries from Central Eastern Europe, members of the EU. Amfiteatru Economic, 18(43), 592-610.

Pfeffer, J., \& Fong, C. T. (2002). The end of business schools? Less success than meets the eye. Academy of Management Learning \& Education, 1(1), 78-95. https://dx.doi. org/10.5465/amle.2002.7373679.

Próchniak, M. (2011). Determinants of economic growth in Central and Eastern
Europe: the global crisis perspective. Postcommunist economies, 23(4), 449-468. https:// dx.doi.org/10.1080/14631377.2011.622566.

Pucciarelli, F., \& Kaplan, A. (2016). Competition and strategy in higher education: Managing complexity and uncertainty. Business Horizons, 59(3), 311-320. https://dx.doi. org/10.1016/j.bushor.2016.01.003.

Rachwał, T., Kurek, S., \& Boguś, M. (2016). Entrepreneurship Education at Secondary Level in Transition Economies: A Case of Poland. Entrepreneurial Business and Economics Review, 4(1), 61-81. https://dx.doi. org/10.15678/EBER.2016.040105.

Saginova, O., \& Belyansky, V. (2008). Facilitating innovations in higher education in transition economies. International Journal of Educational Management, 22(4), 341-351. https://doi.org/10.1108/09513540810875671.

Stankevičienè, J., \& Vaiciukevičiūtè, A. (2016). Value creation for stakeholders in higher education management. E\&M Ekonomie a Management, 19(1), 17-31. https://dx.doi. org/10.15240/tul/001/2016-1-002.

Starkey, K., Hatchuel, A., \& Tempest, S. (2004). Rethinking the business school. Journal of Management Studies, 41(8), 1521-1531. https://dx.doi.org/10.1111/j.14676486.2004.00485.x.

Sursock, A. (2015). Trends 2015: Learning and teaching in European universities. Brussels: European University Association.

Szamosi, L. T., Psychogios, A. G., \& Wood, G. T. (2008). At the Crossroads of Leadership Education in Emerging Economies: Global Relevance Versus Local Applicability. Business Leadership Review, 5(4), 1-9.

Thomas, H., \& Cornuel, E. (2011). Business school futures: evaluation and perspectives. Journal of Management Development, 30(5), 444-450. https://dx.doi. org/10.1108/02621711111132957.

Tran, T. P., Blankson, C., \& Roswinanto, W. (2015). Market orientation: an option for universities to adopt? International Journal of Nonprofit and Voluntary Sector Marketing, 20(4), 347-365. https://dx.doi.org/10.1002/nvsm.1535.

Van Vught, F. (2004). Internationalisation and globalization in European higher education. Twente: University of Twente.

Verner, T. (2011). National Competitiveness and Expenditure on Education, Research and Development. Journal of Competitiveness, 3(2), 3-10. 
Vidaver-Cohen, D. (2007). Reputation beyond the rankings: A conceptual framework for business school research. Corporate Reputation Review, 10(4), 278-304. https://dx.doi.org/10.1057/palgrave.crr.1550055.

Webster, R. L., Hammond, K. L., \& Harmon, H. (2005). Market orientation toward various customer groups in business schools. Academy of Marketing Studies Journal, 9(1), 67-81.

Wedlin, L. (2011). Going global: Rankings as rhetorical devices to construct an international field of management education. Management Learning, 42(2), 199-218. https://dx.doi.org/10.1177/1350507610389683.

Welikala, T. (2011). Rethinking international higher education curriculum: Mapping the research landscape. Universitas 21.

Wilson, D. C., \& Thomas, H. (2012). The legitimacy of the business of business schools: what's the future? Journal of Management Development, 31(4), 368-376. https://dx.doi. org/10.1108/02621711211219040.
Maja Rosi, BSc University of Maribor

Faculty of Tourism Slovenia maja.rosi@um.si

Assoc. Prof. David Tuček, Ph.D. Tomas Bata University in Zlín Faculty of Management and Economics Czech Republic tucek@utb.cz

Full Prof. Vojko Potočan, Ph.D. University of Maribor

Faculty of Economics and Business

Slovenia vojko.potocan@um.si

Assoc. Prof. Milan Jurše, Ph.D. University of Maribor Faculty of Economics and Business

Slovenia milan.jurse@um.si 


\title{
Abstract
}

\section{MARKET ORIENTATION OF BUSINESS SCHOOLS: A DEVELOPMENT OPPORTUNITY FOR THE BUSINESS MODEL OF UNIVERSITY BUSINESS SCHOOLS IN TRANSITION COUNTRIES}

\author{
Maja Rosi, David Tuček, Vojko Potočan, Milan Jurše
}

The adoption of market orientation practices at the Higher Education Institutions is a rising trend, since the challenges of changing the global higher education environment raise a growing issue for meeting the needs of the global market. Developing an appropriate strategy to cope with all of the requirements of the global education market changes and competitive pressures is especially challenging for University Business Schools in transition countries. The paper is based upon an identification of a variety of theoretical perspectives about the global education market, its trends and influences on those schools in the aspects of market orientation. Conceptual framework analysis was used to characterise the market orientation of Business Schools as an opportunity for the strategic business model of University Business Schools in transition countries. Key factors and indicators for understanding their environment were identified, structured and categorised within a theoretical framework. These factors reflect the evolving context of reformation of the existing business model of University Business Schools in transition countries in a comprehensive way, since the framework outlines the complexity of their adaptation, considering the linkages and dependencies of all the crucial global external in internal environment trends and aspects. The authors suggest that, in order to align their business model more adequately to the global market needs and develop a sustainable competitive position, University Business Schools from transition countries have to follow the market orientation principles, taking into account also the limitations and challenges from a wider social and institutional environment.

Key Words: Business education, education quality, market orientation and development, Business Schools, transition countries.

JEL Classification: I24, 125.

DOI: 10.15240/tul/001/2018-4-012 